\title{
Pengaruh Debt to Equity Ratio, Current Ratio, dan Total Asset Turnover terhadap Return on Equity pada Perusahaan Consumer Goods Industry
}

\author{
Indah Astry Wahyuni Sagala ${ }^{1 *}$, Cathrine J Pane ${ }^{2}$, Evrina Yolanda ${ }^{3}$, Ningsih Firda Yanti ${ }^{4}$, \\ Maya Sabirina Panggabean ${ }^{5}$ \\ 1,2,3,4,5 Jurusan Manajemen Keuangan, Fakultas Ekonomi, Universitas Prima Indonesia \\ *Correspondence email: indahsagala1010@gmail.com
}

\begin{abstract}
Debts to Equty, Current Ratio, and Total Turnover of Assets to Return On Equity in the Consumer Goods Industry Company that were found on the Indonesia Stock Exchange for the period 2013-2018. This study uses a sample of 19 Consumer Goods Industry companies that were found on the Indonesia Stock Exchange in the period 2013-2018. This research is quantitative research. The data used are secondary data obtained from the site www.Idx.co.id. The sampling method is Purposive Sampling. Data analysis method used is multiple linear testing. The results showed that the Debt to Equity was insignificant to Return on Capital, the current ratio was calculated partially and significantly to Return on Capital and Total Asset Turnover was not partially related and not significant to Return on Capital. Meanwhile, all independent variables in this study support Return on Equity.
\end{abstract}

Keywords: Debt to equity ratio; Current ratio; Total asset trunover; Return on equity

\section{PENDAHULUAN}

Perkembangan Teknologi saat ini menuntut setiap perusahaan untuk mengembangkan produknya melalui pengembangkan produk yang ada maupun menciptakan yang baru tentu membutuhkan modal yang cukup besar. Berkat teknologi mempermudah pihak perusahaan memperkenalan produk kepada konsumen baik itu konsumen lokal maupun internasional, memperkenalkan produk ke pasar internasional salah satu strategi untuk menarik investor untuk ikut serta menginvestasikan dananya kepada perusahaan.Tentu dengan banyak pertimbangan lainnya,investor harus lebih selektif memilih perusahaan yang tepat untuk melihat bagaimana nasib bisnis tersebut kedepannya.Oleh karena itu,pihak perusahaan harus memiliki kemampuan untuk menarik investor agar mau berinvestasi di perusahaannya,salah satunya dengan meyakinkan investor dengan laporan keuangan perusahaan yang stabil.Peran investor dalam pengembangan perusahaan sangatlah penting,dana dari investor dapat digunakan untuk memperoleh keuntungan yang lebih besar yang dimana kita ketahui keuntungan atau laba tujuan utama dalam sebuah perusahaan.

Perusahaan Consumer Goods Industry bergerak dibidang makan dan minuman yang salah satu sektor perusahaan yang memiliki prospek yang bagus dan tahan terhadap krisis karena produk perusahaan Consumer Goods Industry tersebut merupakan kebutuhan sehari hari yang diperlukan masyarakat yang dimana penjualan dan profit yang diterima oleh perusahaan akan meningkat dan stabil sehingga investor lebih tertarik untuk berinvestasi dengan sektor tersebut.Ketidakstabilan kinerja perusahaan dapat diukur dari laporan keuangan perusahaan itu sendiri salah satunya diukur mrnggunakan rasio-rasio keuangan,rasio Profitabilitas adalah salah satu rasio yang paling diperhatikan oleh investor karena semakin meningkatnya
Return On Equity (ROE) sangat berpengaruh terhadap investasi dalam perusahaan dengan Return On Equity (ROE) yang selalu meningkat bisa dikatakan bahwa perusahaan itu mempunyai kinerja yang baik sehingga para calon investor tertarik untuk menanamkan modal (Fajri et al, 2017). Salah satu perusahaan sektor Consumer Goods Industry yang mengalami permasalahan pada laba bersih yaitu PT.Indofood Sukses Makmur Tbk (INDF) sepanjang semester I 2018 menurun 12,7 persen menjadi 1,96 triliun rupiah dari periode sebelumnya 2,24 triliun rupiah sedangkan penjualan neto naik satu persen menjadi 36 triliun rupiah dibanding periode tahun sebelumnya 35,65 triliun rupiah,Laba bersih menurun dikarenakan meningkatnya hutang perusahaan dari 673 miliar rupiah menjadi 1,12 triliun rupiah.

Adapun beberapa penilitian mengkaji variabel yang sama dalam penelitian ini terhadap Return On Equity (ROE), hasil penelitan dari Adama Fajri et al (2017) menjelaskan bahwa Debt to Equity Ratio (DER) berpengaruh signifikan terhadap Return On Equity (ROE).sedangkan hasil penelitian Adityo Joko Pratomo (2017) menyatakan bahwa Debt to Equity Ratio (DER) tidak berpengaruh signifikan terhadap Return On Equity(ROE.

Menurut penelitian Asyifa Yandra Destari dan Hendratno (2019) menyatakan bahwa Current ratio (CR) tidak berpengaruh signifikan terhadap Return On Equity (ROE) yang mana bertentangan dengan hasil penelitian M. Firza Alpi (2018) menyatakan Current ratio (CR) berpengaruh signifikan terhadap Return On Equity (ROE).

Dalam penelitiannya Eka Dila Dahlia (2017) menyatakan bahwa Total Asset Turnover (TATO) berpengaruh signifikan terhadap Return On Equity $(R O E)$.Tetapi hasil penelitian Sarikadarwati dan Nina 
Afriati (2016) menyatakan bahwa Total Asset Turnover (TATO) tidak berpengaruh signifikan terhadap Return On Equity (ROE). Dari beberapa penelitian terdahulu peneliti ingin meneliti kembali "Pengaruh Debt to Equity Ratio (DER), Current Ratio (CR), Total Asset Turnover (TATO) terhadap Return to Equity (ROE) pada Perusahaan Sektor Consumer Goods Industry yang terdaftar di Bursa Efek Indonesia tahun 2013-2018".

"Return on Equity" merupakan rasio yang memperlihatkan sejauh manakah perusahaan mengelola modal sendiri secara efektif,mengukur tingkat keuntungan dari investasi yang telah dilakukan pemilik modal sendiri atau pemegang saham perusahaan (Sawir, 2014). Rasio ini menunjukkan efisiensi penggunaan modal sendiri. Semakin tinggi rasio ini, samakin baik. Artinya posisi pemilik perusahaan semakin kuat, demikian pula sebaliknya (Kasmir, 2013). Dan diukur dengan rumus:

$R O E=\frac{\text { Laba Bersih }}{\text { Ekuitas }} \times 100 \%$

"Debt to Equity Ratio" merupakan rasio yang digunakan untuk menilai utang dengan ekuitas. Rasio ini berguna untuk mengetahui jumlah dana yang disediakan penjamin (kreditor) dengan pemilik perusahaan. Dengan kata lain, rasio ini berfungsi untuk mengetahui setiap rupiah modal sendiri yang dijadikan untuk jaminan utang" (Kasmir, 2014). Semakin tinggi Debt to Equity Ratio semakin besar jumlah modal pinjaman yang digunakan didalam menghasilkan keuntungan bagi perusahaan (Syamsudin, 2011). Dan diukur dengan rumus:

Debt to Equity Ratio $=\frac{\text { Total Debt }}{\text { Total Ekuitas }} \times 100 \%$

"Current Ratio adalah ukuran yang umum yang digunakan atas solves jangka pendek, kemampuan suatu perusahaan memenuhi kebutuhan utang ketika jatuh tempo (Fahmi, 2016). Semakin tinggi rasio lancar,maka akan semakin besar kemampuan perusahaan untuk membayar berbagai tagihannya;akan tetapi, rasio ini harus dianggap sebagai ukuran kasar karena tidak memperhitungkan likuiditas (liquidity) dari setiap komponen aset lancar (James, 2013) Dan diukur dengan rumus:

Current Ratio $=\frac{\text { Aktiva lancar }}{\text { Utang lancar }} \times 100 \%$

“Total Asset Turnover"Merupakan rasio yang menunjukkan tingkat efesiensi penggunaan keseluruhan aktiva perusahaan di dalam menghasilkan volume penjualan tertentu.Semakin tinggi ratio Total Asset Turnover berarti semakin efisien penggunaan keseluruhan aktiva didalam menghasilkan penjualan.
Dengan perkataan lain,jumlah asset yang sama dapat memperbesar volume penjualan apabila Total Asset Turnovernya di tingkatkan atau diperbesar (Syamsudin, 2011).

Rasio Perputaran Total Asset $=\frac{\text { Penjualan }}{\text { Total Asset }} \times 100 \%$

\section{METODE}

Metode yang digunakan di penelitian ini adalah metode deskriptif merupakan penelitian yang digunakan untuk menganalisa data,Jenis penelitian ini adalah penelitian deskriptif dengan cara mendeskriptifkan atau menggambarkan data yang telah terkumpulkan sebagimana adanya tanpa bermaksud membuat kesimpulan yang berlaku untuk umum atau generalisasi (Sugiyono, 2016).

\section{Populasi dan Sampel}

Penelitian ini menggunakan teknik purposive sampling. Menurut Sugiyono (2016), purposive sampling adalah teknik pengambilan sampel sumber data dengan pertimbangan tertentu.Dalam penelitian yang digunakan adalah perusahaan sektor Consumer Goods Industry yang terdaftar di Bursa Efek Indonesia Periode 2013-2018 sebanyak 42 perusahaan jumlah sampel 19, total sampel selama periode berjalan $(19 \times 6)=114$.

\section{Jenis dan Sumber Data}

Jenis penelitian ini adalah jenis data kuntatitatif yang bersumber dari data sekunder yaitu data yang di peroleh dari laporan keuangan perusahaan. Sumber data sekunder ini diperoleh dari laporan keungan Perusahaan Sektor Consumer Goods Industry pada periode 20132018.

\section{Model Penelitian}

Menurut Sugiyono (2018), menyatakan bawa uji regresi linier berganda digunakan oleh peneliti bila bermaksud meramalkan bagaimana keadaan (naik turunnya) variable independen bila kedua ataua lebih independen atau sebagai faktor kreditor dimanipulasi (dinaikan nilanya).

$\mathrm{Y}=\mathrm{a}+\mathrm{b}_{1} \mathrm{X}_{1}+\mathrm{b}_{2} \mathrm{X}_{2}+\mathrm{b}_{3} \mathrm{X}_{3}+\mathrm{e}$

Keterangan:

$\mathrm{Y} \quad=$ Return On Equity $(R O E)$

$\mathrm{X}_{1} \quad=$ Debt to equity ratio $(D E R)$

$\mathrm{X}_{2} \quad=$ Current ratio(CR)

$\mathrm{X}_{3}=$ Total asset trunover(TATO)

a $=$ Konstanta

$\mathrm{b}(1,2,3)=$ Nilai koefisien regresi

\section{Uji Koifisien Determinasi $\left(\mathbf{R}^{\mathbf{2}}\right)$}

Menurut Ghozali (2013), menyatakan bahwa koefisien determinasi $\left(\mathrm{R}^{2}\right)$ adjested pada intinya 
mengukur seberapa jauh kemampuan model dalam menerangkan variasi variable independen

\section{Pengujian Hipotesis Secara Simultan (UjiF)}

Secara simultan pengujian hipotesis dilakukan dengan uji F-test. Menurut Ghozali (2013) uji statistik F pada dasarnya menunjukkan apakah semua variabel independen atau bebas yang dimasukkan dalam model mempunyai pangaruh secara bersama-sama terhadap variabel independen/terikat ,Hipotesis:

1. Ho : $\mathrm{X} 1, \mathrm{X} 2$ dan $\mathrm{X} 3=0$ (artinya bahwa tidak ada pengaruh secara bersama-sama dari seluruh variabel independen terhadap variabeldependen).

2. Ha : $\mathrm{X} 1, \mathrm{X} 2$ dan $\mathrm{X} 3 \neq 0$ (artinya bahwa terdapat pengaruh secara bersama-sama daei seluruh variabel independen terhadap variabeldependen).

Untuk megetahui apakah hipotesis yang diajukan diterima atau ditolak adalah dengan membandingkan nilai Fhitung dengan Ftabel pada tingkat kepercayaan $95 \%(\alpha=0,05)$.Kriteria pengambilan keputusan adalah: $\mathrm{H}_{\mathrm{a}}$ diterima dan $\mathrm{H} 0$ ditolak jika nilai Fhitung $>$ Ftabel pada $\alpha=0,05$.

\section{Pengujian Hipotesis Secara Parsial (Ujit)}

Menurut Ghozali (2013), Menyatakan bahwa uji statistik t pada dasarnya menunjukkan seberapa jauh pengaruh satu variabel pebjelas/independen secara individual dalam menerangkan variasi variabel dependen. Hipotesis:

1. HO : $\mathrm{X} 1=0$ (artinya variabel dependen tersebut bukan merupakan penjelas yang signifikan terhadap variabeldependen)

2. $\mathrm{Ha}: \mathrm{X} 1 \neq 0$ (artinya variabel dependen tersebut merupakan penjelas yang signifikan terhadap variabeldependen).

Untuk mengetahui apakah hipotesis yang diajukan diterima atau ditolak, nilai thitung akan dibandaingkan dengan ttabel pada tingkat kepercayaan 95\% $(\alpha=0,05)$. Kriteria pengambilan keputusan adalah:

$\mathrm{Ha}$ diterima dan $\mathrm{H} 0$ ditolak jika nilai- thitung<-ttabel atau pada $\alpha=0,05$.

\section{HASIL DAN PEMBAHASAN Statistik Deskriptif}

Statistik Deskriptif digunakan untuk menggamabarkan tentang ringkasan dari data-data penelitian seperti maksimum, minimum, mean, dan standar deviasi dari masing-masing variabel.

Tabel 1. Descriptive Statistics

\begin{tabular}{lrrrrr}
\hline & $\mathrm{N}$ & \multicolumn{1}{c}{ Minimum } & \multicolumn{1}{c}{ Maximum } & \multicolumn{1}{c}{ Mean } & Std. Deviation \\
\hline DER & 114 &, 00 & 303,00 & 67,7018 & 48,62625 \\
CR & 114 & 51,00 & 717,00 & 247,2105 & \\
TATO & 114 & 13,00 & 310,00 & 138,1579 & 56,98278 \\
ROE & 114 & 2,00 & 540,00 & 34,9912 & 82,53929 \\
Valid N (listwise) & 114 & & & & \\
\hline
\end{tabular}

Sumber:Data di olah SPSS, 2019

Berdasarkan Tabel IV.1 statistik deskriptif dapat dijelaskan bahwa jumlah pengamatan data pada perusahaan Sektor Consumer Good Industry yang terdaftar di Bursa Efek Indonesia periode 2013-2018 dalam penelitian ini sebanyak 19perusahaan dengan total data 114 sampel.Pada variabel bebas debt to equity ratio (DER) diketahui nilai minimum sebesar 0,00 persen dan nilai maksimumnya sebesar 303,00 persen serta mean atau nilai rata-rata variabel debt to equity ratio (DER) sebesar 67,7018 dan Standar deviasi debt to equity ratio (DER) adalah sebesar48,62625.Pada variabel bebas current ratio (CR) diketahui nilai minimum menunjukkan angka 51,00 persen dan nilai maksimumnya sebesar 717,00 persen Serta mean variabel bebas current ratio (CR) sebesar 247,2105 dan Standar deviasi current ratio (CR) adalah sebesar130,04380. Variabel bebas dalam penelitian ini ialah total asset turnover(TATO) diketahui nilai minimum sebesar 13,00 persen dan nilai maksimumnya sebesar 310,00 serta mean atau nilai rata-rata variabel total asset turnover(TATO) sebesar 138,1579 dan Standar deviasi total asset turnover(TATO) adalah sebesar 56,98278.

\section{Hasil Uji Asumsi klasik Uji Normalitas}

Untuk mendeteksi normalitas dan dapat juga dilakukan dengan non-parametic statistic dengan uji kolmogrov-sminorv (K-S) jika sig $>0,05$ maka distribusi normal dan jika sig $<0,05$ maka distribusi tidak normal (Ghozali, 2016).

\section{Uji Multikolonieritas}

Uji multikolonieritas bertujuan untuk menguji apakah model regresi ditemukan adanya kolerasi anatar variabel bebas (independen).Jika nilai tolerance yang rendah sama dengan nilai VIF tinggi (karena $\mathrm{VIF}=1 /$ tolerance)di pakai untuk menunjukkan adanya multikolonieritas nilai tolerance $>0,10$ atau sama dengan nilai VIF<10 (Ghozali, 2016).

\section{Uji Heteroskedastisitas}

Adalah menyatakan bahwa uji heteroskedastisitas bertujuan menguji apakah dalam model regresi terjadi 
ketiksamaan variance dari residualsatu pengamatan kepengamatan yang lain (Ghozali, 2013).

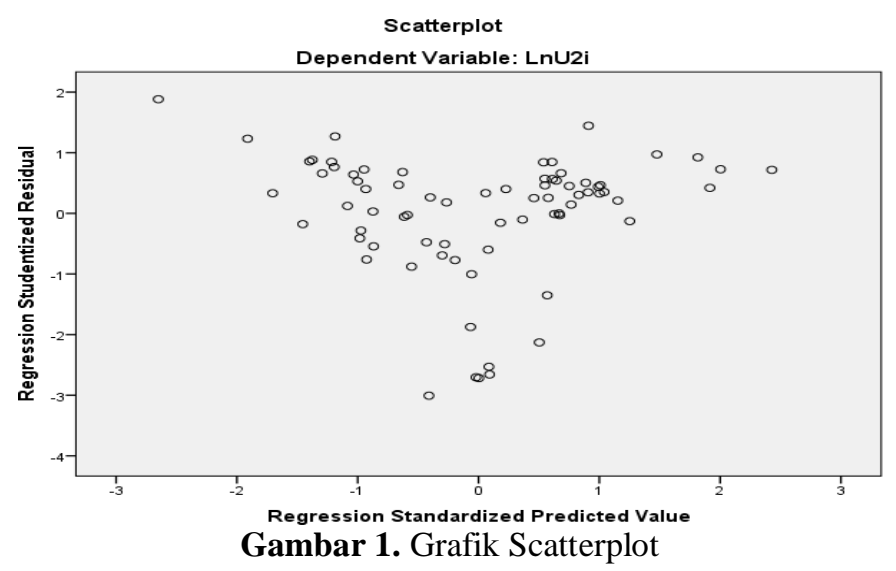

Sumber: Data olahan SPSS, 2019

Gambar 1 menunjukkan penyebaran titik-titikyang secara acak baik diatas maupun dibawah angka nol (0) pada sumbu Y, hal ini dapat diindikasikan bahwa tidak terjadi heteroskedastisitas dalam model regresi penelitian ini.

\section{Uji Autokolerasi}

Menyatakan bahwa uji autokolerasi bertujuan untuk menguji apakah dalam model regresi linier ada kolerasi antara kesalahan pada periode dengan kesalahan pengganggu pada periode t-1 sebelumnya (Ghozali, 2013). Nilai Durbin-Watson sebesar 2,147 sedangkan nilai dw sebesar 1.6410, nilai du sebesar 1.7488 dan nilai 4-DU 2,2512. Artinya adalah $\mathrm{DU}<\mathrm{DW}<4-\mathrm{DU}$ dimana $1,7488<2,147<2,2512$ dapat disimpulkan tidak terjadi masalah autokorelasi dalam model regresi penelitian ini.

\section{Regresi linier berganda}

Menurut Sugiyono (2018), menyatakan bawa uji regresi linier berganda digunakan oleh peneliti bila bermaksud meramalkan bagaimana keadaan (naik turunnya) variable independen bila kedua ataua lebih independen atau sebagai faktor kreditor dimanipulasi (dinaikan nilainya).

Tabel 2. Hasil Uji Regresi linier berganda

\begin{tabular}{llrr}
\hline \multirow{2}{*}{ Model } & \multicolumn{2}{c}{ Unstandardized Coefficients } \\
\cline { 3 - 4 } & & \multicolumn{1}{c}{ B } & Std. Error \\
\hline \multirow{2}{*}{1 (Constant) } & 5,337 & 1,583 \\
& Ln_DER &, 185 &, 107 \\
& Ln_CR &,- 525 &, 180 \\
& Ln_TATO &,- 094 &, 195 \\
\hline
\end{tabular}

a. Dependent Variable: Ln_ROE

Sumber: Data olahan SPSS, 2019

Pada tabel 2 unstandardized cofficients pada bagian B,maka diperoleh persamaan regresi linier berganda LN_Return on Equity $=5,337+0,185 \mathrm{LN} \_d e b t$ to equity ratio (DER)-0,525LN_ current ratio(CR) 0,094 LN_total asset turnover (TATO) +e

Dari tabel di atas dapat disimpulkan bahwa:

1. Nilai konstanta $(\alpha)$ sebesar 5,337 maka jika variabel Debt to Equity Ratio,Current Ratio, Total Asset Turnover, dianggap konstan/tetap atau nol maka Return on Eqity akan meningkat sebesar 5,337 persen.

2. Nilai kofisien variabel Debt to Equity Ratio ( $\beta 1)$ sebesar 185 yang dimana jika setiap kenaikan Debt to Equity Ratio 1 persen maka Return on Equity akan meningkat sebesar 1,85 persen.

3. Nilai kofisien variabel Current Ratio ( $\beta 2$ ) sebesar 525 yang dimana jika setiap penurunan Current Ratio 1 persen maka Return on Equity akan menurun sebesar 5,25 persen.

4. Nilai kofisien variabel Total Asset Turnover ( $\beta 3)$ sebesar -094 yang dimana jika setiap penurunan Total Asset Turnover 1 persen maka Return on Equity akan menurun sebesar 9,4 persen.

Tabel 3. Uji t dan Uji f

\begin{tabular}{|c|c|c|c|c|c|}
\hline \multirow{2}{*}{ Model } & & Standardized Coefficients & \multirow{2}{*}{$\mathbf{T}$} & \multirow{2}{*}{ Sig. } & \multirow{2}{*}{$\mathbf{F}$} \\
\hline & & Beta & & & \\
\hline 1 & $\begin{array}{l}\quad \text { (Constant) } \\
\text { Ln_DER } \\
\text { Ln_CR } \\
\text { Ln_TATO }\end{array}$ & $\begin{array}{r}, 173 \\
-, 291 \\
-, 042\end{array}$ & $\begin{array}{r}3,370 \\
1,733 \\
-2,922 \\
-, 483 \\
\end{array}$ & $\begin{array}{l}, 001 \\
, 086 \\
, 004 \\
, 630\end{array}$ & 7,184 \\
\hline
\end{tabular}

a. Dependent Variable: Ln_ROE

Sumber: Data olahan SPSS, 2019

Dari tabel di atas dapat diketahui nilai Fhitung menunjukkan angka sebesar 7,184 dengan nilai signifikansi dibawah 0,05 yaitu sebesar 0,000 . Berdasarkan kententuan yang terdapat bahwa nilai Fhitung $>$ Ftabel dan dimana nilai Ftabel dengan jumlah pembilang (df1) sebesar 3 serta jumlah untuk penyebut (df2) adalah 110 dengan hasil Ftabel ialah 2,69 maka hasil dari statistik uji Fhitung >Ftabel $(7,184>2,69)$ menunjukan variabel Debt to Equity Ratio (DER),Current Ratio (CR) dan Total Asset Turnover (TATO) secara simultan berpengaruh dan signifikan terhadap return on equity (ROE) pada perusahaan Sektor Consumer good industry yang terdaftar di Bursa Efek Indonesia Periode 2013-2018. 
Dari perhitungan thitung yang menampilkan signifikansi sebesar 0,001 dengan degree of freedom 110 menunjukkan hasil ttabel sebesar 1.98197.

1. Untuk hasil uji thitung <ttabel untuk variabel sebesar $1,733<1.98197$, dengan signifikansi 0,086> 0,05 mengidentifikasikan bahwa variabel Debt to Equity Ratio (DER) tidak berpengaruh terhadap Return on Equity. Hal ini ditunjukkan dengan perbandingan thitung < ttabel $(1,733<1.98197)$.maka keputusannya bahwa Debt to Equity Ratio (DER) secara parsial tidak berpengaruh dan tidak signifikan terhadap Return on Equity pada perusahaan Sektor Consumer Goods Industry yang terdaftar di Bursa Efek Indonesia Periode 2013-2018.

2. Untuk hasil uji-thitung<-ttabel untuk variable Current ratio (CR) adalah sebesar $(-2,922<-$ 1.98197), dengan signifikansi $0,004<0,05$ mengindikasikan bahwa variabel current ratio (CR) berpengaruh terhadap return on equity. Hal ini ditunjukkan dengan perbandingan - thitung <-ttabel ($2,922<-1.98197)$ maka diketahui bahwa Current ratio $(\mathrm{CR})$ secara parsial berpengaruh dan signifikan terhadap Return on Equity pada perusahaan Sektor consumer good industry yang terdaftar di Bursa Efek Indonesia Periode 2013-2018.

3. Untuk hasil uji -thitung >-ttabel untuk variabel Total Asset Turnover (TATO) adalah sebesar - 0,483>1.98197, dengan signifikansi $0,630>0,05$ mengindikasikan bahwa variabel Total Asset Turnover (TATO) tidak berpengaruh terhadap Return on Equity. Hal ini ditunjukkan dengan perbandingan thitung >-ttabel (-0,483>-1.98197) maka diketahui bahwa Total Asset Turnover (TATO) secara parsial tidak berpengaruh dan tidak signifikan terhadap Return on Equity pada perusahaan Sektor Consumer good industry yang terdaftar di Bursa Efek Indonesia Periode 2013-2018.

Tabel 4. Hasil uji Koefisien Determinasi

\begin{tabular}{llrrrr}
\multicolumn{7}{c}{ Model Summary } \\
\hline Model & $\mathrm{R}$ & R Square & Adjusted R Square & Std. Error of the Estimate & Durbin-Watson \\
\hline 1 &, $406^{\mathrm{a}}$ &, 165 &, 142 &, 87532 &, 719 \\
\hline
\end{tabular}

a.Predictors: (Constant), Ln_TATO, Ln_CR,Ln_DER

b.Dependent Variable:Ln_ROE

Sumber: Data olahan SPSS, 2019

Tabel 4, menunjukkan bahwa nilai R Square yang diperoleh adalah 0,142. Artinya 14,2\% Return on Equity (ROE) sebagai variabel terikat dapat dijelaskan oleh variasi dari variabel bebas yaitu Debt to Equity Ratio (DER), Current Ratio (CR) dan Total Asset Turnover (TATO). Sedangkan $85,8 \%$ dapat dijelaskan oleh faktor lainnya yang tidak diteliti diluar model penelitian ini.

\section{SIMPULAN}

Debt to Equity Ratio (DER) secara parsial tidak berpengaruh dan tidak signifikan terhadap Return on Equity pada perusahaan Sektor Consumer good industry yang terdaftar di Bursa Efek Indonesia Periode 20132018. dengan hasil perbandingan thitung < tabel $(1,733<1.98197)$ Penelitain ini sejalan dengan penelitian sebelumnya yang membahas tentang pengaruh terhadap Debt to Equity Ratio(DER) yang di teliti oleh Adityo Joko Pratomo (2017), dengan hasil penelitian bahwa Debt to Equity Ratio (DER) tidak berpengaruh secra parsial dan tidak signifikan terhadap Return on Equity. penggunaan utang yang terlalu tinggi akan membahayakan perusahaan karena perusahaan akan masuk dalam kategori extreme leverage (utang ekstrim) yaitu perusahaan terjebak dalam tingkat utang yang tinggi dan sulit untuk melepaskan beban utang tersebut (Fahmi, 2016).

Current ratio (CR) secara parsial berpengaruh dan signifikan terhadap return on equity pada perusahaan
Sektor consumer good industry yang terdaftar di Bursa Efek Indonesia Periode 2013-2018. Dengan hasil perbandingan thitung $<$ tabel $(-2,922<-1.98197)$ Penelitain ini sejalan dengan penelitian sebelumnya yang membahas tentang pengaruh terhadap Current Ratio(CR) Terhadap Return on Equity .Penelitian ini di teliti oleh M. Firza Alpi (2018), dengan hasil penelitian bahwa Current Ratio (CR) secara parsial berpengaruh dan signifikan terhadap Return on equity. kemampuan perusahaan suatu perusahaan memenuhi kewajiban jangka pendeknya secara tepat waktu. Kemampuan memenuhi kewajiban lancar yaitu semakin tinggi jumlah (kelipatan) asset lancar terhadap kewajiban lancar, makin besar keyakinan bahwa kewajiban lancar tersebut akan dibayar. Penyangga kerugian, makin besar penyangga mekin kecil resikonya.Rasio lancar menunjukkan tingkat keamanan yang tersedia untuk menutup penurunan nilai asset lancar non-kas pada saat asset tersebut dilepas atau dilikuidasi (Fahmi, 2016).

Total asset turnover (TATO) secara parsial tidak berpengaruh dan tidak signifikan terhadap Return on Equity pada perusahaan Sektor consumer good industry yang terdaftar di Bursa Efek Indonesia Periode 20132018, dengan hasil perbandingan -thitung> -ttabel (0,483 >-1.98197). Penelitain ini sejalan dengan penelitian sebelumnya yang membahas tentang berpengaruh terhadapTotal asset Trun Over Terhadap Return on Equity. Penelitian ini di teliti oleh Sharon et al 
(2015), dengan hasil penelitian bahwa Total asset Trun Over secara parsial berpengaruh dan tidak signifikan terhadap Return on equity.

Makin tinggi nilai Total Asset Turnover akan makin baik karena itu berarti semua asset perusahaan dapat memberi kontribusi yang besar bagi pencapaian laba perusahaan.Semakin besar rasio ini semakin baik karena perusahaan tersebut dianggap efektif dalam mengelola assetnya.

Debt to Equity (DER), Current Ratio (CR), dan Total asset Trun Over (TATO) secara simultan berpengaruh dan signifikan terhadap Return on Equity pada perusahan Sektor consumer good industry yang terdaftar di Bursa Efek Indonesia Periode 2013-2018 dengan Fhitung $\geq$ Ftabel $(7,184 \geq 2,69)$ dan signifikansi 000 .

\section{DAFTAR PUSTAKA}

Alfi, Firza. M. (2018). Pengaruh Debt To Equity Ratio Inventory Turnover dan Current Ratio Terhadap Return On Equity pada Perusahaan Sektor Farmasi yang Terdaftar di Bursa Efek Indonesia. Jurnal Fakultas Ekonomi dan Bisnis, 2621-1572.

Dahlia, Dila, Eka. (2017). Pengaruh Net Profit Margin dan Total Asset Turn over terhadap Return On Equity Ratio pada Perusahaan LQ45 yang Terdaftar di Bursa Efek Indonesia. Jurnal Fakultas Ekonomi, 03(6), 2407-8565.

Destarim, Yandra Asyifa. Hedratno. (2019). Analisis pengaruh Debt to Equity Ratio,Current Ratio,Total Asset Turnover dan size terhadap Return on Equity. Jurnal akuntansi, audit dan system informasi akuntansi, 03(1),2655-8319.

Fahmi, Irham. 2016. Pengantar Manajemen Keuangan. Bandung: CV Alfabeta.

Fajri, Adama. Rahayu, Sri. Kurnia. (2017). Pengaruh Current Ratio, Debt to Equity Ratio Dan Total Asset Turnover Terhadap Return On Equity (Study pada sector Industri Kimia dan farmasi yang terdaftar di Bursa efek Indonesia tahun 20112016, 4(2), 2355-9357.

Ghozali, Imam. (2013). "Aplikasi Analisis multivariate”. Semarang: Badan Penerbit Universitas Diponegoro.

Ghozali, Imam. (2016). Aplikasi Analisis Multivariete Dengan Program IBM SPSS. Semarang: Badan Penerbit Universitas Diponegoro.

Horne, Van, James C dan Wachowicz, Ir., John M., 2013. Prinsip-Prinsip Manajemen Keuangan Fundamentals of Financial Manaegement, Buku 2, ed. 13, Salemba Empat, Jakarta.

Kasmir., 2013. Analisis Laporan Keuangan. Jakarta: Rajawali Pers

Kasmir. 2014. Analisis Laporan Keuangan. Edisi Satu. Cetakan Ketujuh. Jakarta: PT Raja Grafindo Persada
Pantow, Mawar Sharon R., Sri Murni dan Irvan Trang. 2015. Analisa Pertumbuhan Penjualan, Ukuran Perusahaan, Return On Asset, Dan Struktur Modal Terhadap Nilai Perusahaan Yang Tercatat di Indeks LQ 45. Jurnal EMBA Vol.3 No.1 Maret 2015, Hal.961-971

Pratomo, Joko Adityo. (2017). Pengaruh Debt to Equity Ratio (DER) Dan Current Ratio (CR) Terhadap Return on Equity (ROE). Studi Empiris Pada Perusahaan Sub Sektor Kabel Yang Terdaftar di Bursa Efek Indonesia Pada Tahun 2013-2016. Jurnal Administrasi Bisnis,5(4),942-956.

Prof. Dr. Sugiyono. 2018. Metode Penelitian Kuantitatif, Kualitatif, dan R\&D. Bandung: Alfabeta.

Sawir, Agnes. (2014). "Analisis kinerja keuangan dan perencanaan keuangan Jakarta: PT Gramedia pustaka utama.

Sarikadarwati, Afriati, Nina.(2016). Analisis pengaruh Debt to Equity Ratio (DER), Total Asset Turnover (TATO) terhadap Return On Equity (ROE). Pada perusahaan manufaktur sub-sektor Farmasi di Bursa efek Indonesia tahun 2008-2012.jurnal Akutansi politeknik sekayu(ACSY).2,2407-2184.

Sugiyono. 2016. Metode Penelitian Kuantitatif, Kualitatif dan $R \& D$. Bandung: Alfabeta

Syamsudin, Lukman. (2011). "Manajemen keuangan perusahaan”. Jakarta: PT Grafindo persada. 